Галасюк В. В., к.е.н., Голова Комітету Верховної Ради України з питань промислової політики та підприємництва, Президент Української асоціації Римського Клубу

\title{
АКТУАЛЬНІ ПРОБЛЕМИ ВИХОДУ УКРАЇНИ НА ПОЗИТИВНУ ТРАЕКТОРІЮ ЕКОНОМІЧНОГО ЗРОСТАННЯ
}

У статті порушено проблему подолання хронічних проблем української економіки та забезпечення ії випереджаючого розвитку на шляху європейської інтеграції. Охарактеризовано тенденції економічного занепаду в Україні за часів переходу до ринкової економіки. Проведено порівняльний аналіз соціально-економічної динаміки України й низки інших країн, що мали приблизно однакові з нею стартові позиції розвитку національного господарства наприкінці XX ст. Визначено виклики європейської інтеграції для України в контексті забезпечення економічної конвергенції з ЄС. Обґрунтовано необхідність глибокої структурної трансформації вітчизняної економіки на противагу поверховим неоліберальним реформам, проведених за часи незалежності.

Ключові слова: валовий внутрішній продукт, сировинно-борговий дрейф, економічний занепад, структурна трансформація, євроінтеграція, економічна політика, економічний розвиток.

Постановка проблеми. За роки незалежності Україні не досі вдалося побудувати ефективну економічну систему, здатну забезпечувати належний рівень життя населення та зберігати стійкість перед сучасними викликами розвитку світового господарства. Україна потерпає від наслідків економічної депресії. Вітчизняна економіка потребує невідкладної фахової діагностики, реанімації та розвитку, а не імітації реформ - політики невтручання держави та спостерігання за «вільним падінням» економіки. Економічна динаміка країни наочно демонструє, що відсторонене спостерігання за дією «невидимої руки ринку» та консервація поточного тренду ВВП - шлях до економічної околиці. У зв'язку з цим актуальності набуває необхідність переосмислення того, як та з яких саме причин відбувається дедалі більше поглиблення розриву в рівні економічного розвитку України й переважної більшості заможних країн.

Аналіз останніх досліджень і публікацій. Дослідженню передумов і причин посилення хронічних проблем вітчизняної економіки присвячено наукові доробки низки провідних українських вчених, 
зокрема Б.М. Данилишина [1], П.С. Єщенко [2; 3], Л.Б. Колінець [4], Я.П. Квач [5], В.А. Голян [6], І.Ю. Гужва [7], Є.І. Іванов [8] і багато інших. У їх працях висвітлюються базові причини і наслідки поширення перманентних кризових явищ в економіці України, на теоретичному рівні обґрунтовується згубність і безперспективність сучасної моделі економічного розвитку України як постачальника сировини й напівфабрикатів у виробничо-збутові мережі розвинутих країн світу, доводиться неадекватність вітчизняної економічної політики реаліям сучасного стану національного господарства. Поряд 3 цим слід зазначити, що попри наявні напрацювання низка проблем і викликів для виходу України на позитивну траєкторію економічного зростання, зокрема тих, що постали в результаті їі євроінтеграційних устремлінь, залишаються недостатньо висвітленими у науковій літературі, що потребує подальших досліджень.

Мета статті полягає у визначенні ключових причин та наслідків обрання Україною неефективної моделі розвитку у період ринкових трансформацій й обґрунтуванні необхідності докорінного перегляду фундаментальних засад і підходів до реалізації державної економічної політики.

Виклад основного матеріалу. Україна - це Європа географічно та цивілізаційно. Але економічно ми ще далеко не європейці. За рівнем розвитку економіки це спостерігається за рівнем ВВП на душу населення, Україна відстає від ЄС практично в 5 разів, а від США майже всемеро [9]. Такий низький рівень економічної активності країни обмежує як доходи людей так і можливості бюджетного фінансування освіти, медицини, соціальної сфери, не кажучи вже про інфраструктуру. Формується «замкнене коло» бідності населення i економічної слабкості країни.

Як то кажуть, вище голови не стрибнеш. За світовим досвідом, оплата праці в країні становить близько 40-50\% ВВП [10]. Тобто в бідній країні люди (переважна більшість населення, а не окремі індивіди звісно) не можуть отримувати високі доходи. Водій в Києві заробляє 300 євро, майже в 10 разів менше за свого колегу з Лондону, не тому що він менш професійний чи ефективний. Різний рівень економічної активності країн, різний рівень оплати праці. Зворотна логіка теж працює. Чим менше люди заробляють, тим менше їх видатки i, відповідно, внесок у зростання ВВП. До речі, видатки домогосподарств в Україні формують понад 2/3 економіки [11].

Незважаючи на «неідеальність» та усю справедливу критику ВВП, він все ж таки $є$ одним з центральних економічних індикаторів, тісно пов'язаних з рівнем добробуту людей і навіть з їх суб'єктивним 
відчуттям щастя. Показник ВВП дозволяє проводити міжнародні порівняння та спостерігати економічну динаміку країн з плином часу. Цікаво відслідкувати економічну траєкторію України за період незалежності. I порівняти ії з сусідніми країнами та тими, хто в 90-ті «починав» зі схожих стартових умов. Після падіння «залізної завіси» $\mathrm{i}$ розвалу СРСР, враховуючи величезне ресурсне багатство України, цілком логічними були очікування стрімкого зростання нашої економіки. На це розраховували в Україні, у це вірила українська діаспора по всьому світу. Проте не так сталося як гадалося. Україна, на жаль, увійшла до «клубу» країн, які примудрились з 1991 по 2017 рік втратити частину свого ВВП в реальному вимірі. Таких, за даними Світового банку [12], в Європі виявилось лише дві: Україна та Молдова. Всі інші країни наростили свою економіку. Найменш успішні - на десятки відсотків, лідери ж-у 2-3 рази (рис. 1).

На перший погляд може здатися, що реальне зменшення «економічного пирога» Україні $€$ методологічною помилкою в розрахунках або якимось статистичним парадоксом. Адже якби українець потрапив з 1991 у 2018 рік, він навряд чи погодився б з тим, що нинішнє економічне становище гірше ніж те, в якому держава знаходилась на початку незалежності. Насправді, $є$ як мінімум два значних фактори через ситуація на графіку і в житті виглядає по-різному.

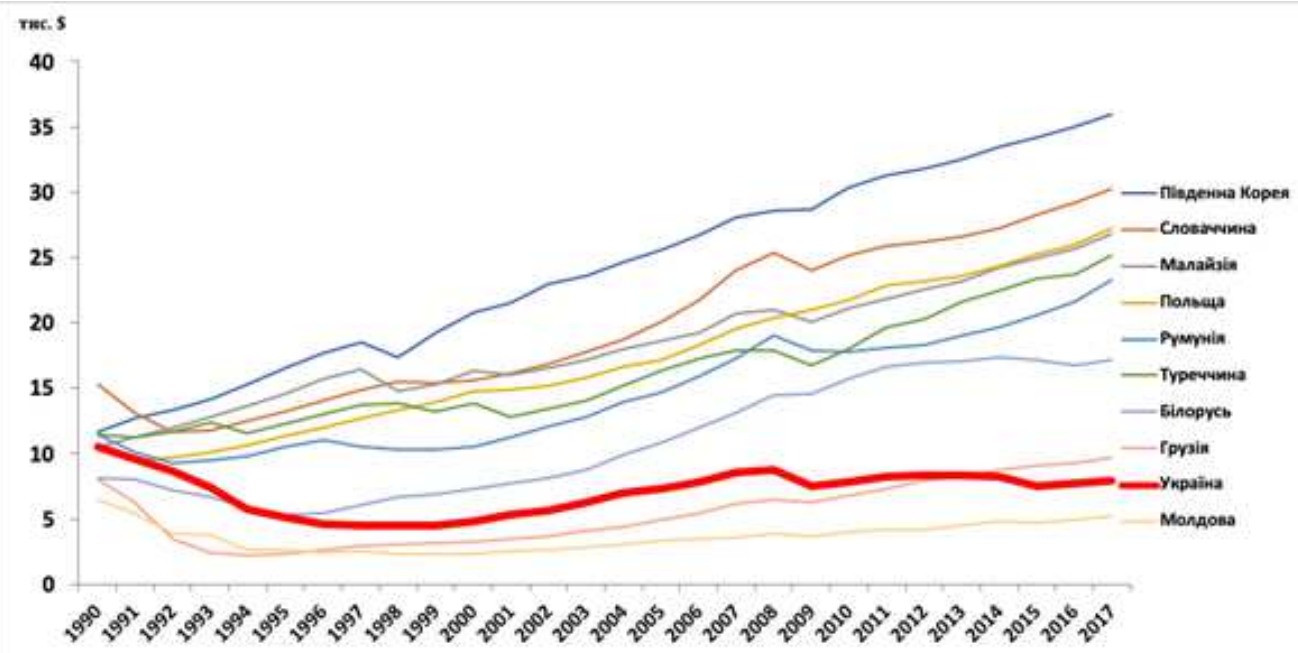

Рис. 1. Динаміка ВВП України та інших країн світу у 1990-2017рр. Джерело: [12]

Перший - надмірна мілітаризація економіки пострадянської України. Економіка була для армії, а не для людей. Вона була орієнтована на військові та інші ресурсні потреби Москви, а не на задоволення потреб суспільства та якість життя власних громадян. Другий - надзвичайно висока тінізація економіки. Варто підкреслити, що 
вона спрацювала як своєрідний «амортизатор» негативних економічних трендів, знижуючи масштаб їх негативного соціального впливу. За оцінками МВФ неформальний сектор в Україні становить від $40 \%$ до 50\% офіційної економіки. Тоді як в Європі «в тіні» не більше 15\% економічної активності [13]. Тому насправді економічна динаміка України не настільки погана, як виглядає на вищенаведеному графіку.

Але ці два фактори, демілітаризація і тінізація економіки, все ж жодним чином не виправдовують і не рятують економічну ситуацію. Це чітко видно, якщо порівняти нічні знімки Європи, зроблені з космосу американськими військовими супутниками (DMSP) у 1993 та 2013 роках [14]. На думку вчених нічне освітлення може розглядатись як наочний індикатор людської активності, а отже і економічного розвитку. Якщо країна з часом стає «яскравішою» вночі - значить там відбувається розвиток, економічна активність і добробут людей зростають. Коли ж країна з плином років тьмяніє вночі - це означає, що життя там чомусь «завмирає», люди біднішають.

Світлові мапи наочно демонструють принаймні два економічні тренди. Перший - за 20 років рівень нічного освітлення України загалом знизився, тоді як сусідні Польща, Туреччина, Румунія, не кажучи вже про Німеччину чи Італію, навпаки - стали значно «яскравішими» вночі. Тобто економічна статистика Світового Банку, яка демонструє економічну траєкторію України у порівнянні 3 іншими країнами на основі ВВП на душу населення, знаходить опосередковане емпіричне підтвердження і через порівняльний аналіз світлових мап.

Другий важливий тренд - нерівномірність економічної динаміки всередині країни. За 20 років Київ - єдине українське місто, яке стало «яскравішим» на світловій мапі. Країна ж в цілому помітно потьмяніла. Причому менше світла стало і в обласних центрах і, ще помітніше, в невеликих населених пунктах. Ці контрастні зміни свідчать про економічну деградацію переважної частини території країни з одночасним «стягуванням» економічних активностей до столиці. Взагалі-то, парадоксальна негативна економічна динаміка на фоні виключного ресурсного багатства країни.

Не менш важливим $€$ тут і ще один вимір - соціальнодемографічний. Він, з одного боку, залежить від економіки, а з іншого - $є$ детермінантом їі розвитку. Відклавши по одній осі ВВП (рівень економічної активності), а по іншій чисельність населення (соціально-демографічний аспект), отримаємо більш глибоке розуміння соціально-економічної траєкторії країни. Співставивши такі двовимірні 
графіки для України з одного боку і Польщі, Туреччини, Словаччини, Білорусі з іншого, наочно бачимо який шлях ми, українці, пройшли відносно наших сусідів за чверть сторіччя (рис. 2).

Особливо показовим $€$ порівняння соціально-економічного шляху України та Туреччини. Україна втратила не лише більше чверті економіки в реальному вимірі, а й майже $10 \mathrm{mлн} \mathrm{населення.} \mathrm{За} \mathrm{цей}$ же період часу Туреччина майже вдвічі збільшила чисельність мешканців і практично втричі наростила національний «економічний пиріг» в розрахунку на душу населення. Показово, що соціальноекономічні траєкторії України і Туреччини майже діаметрально протилежні. До речі, як і тип проваджуваної ними економічної політики. Ефективність агресивної промислово-інвестиційної політики і багатовимірного протекціонізму Туреччини виглядає особливо гротескно на фоні сировинно-боргового дрейфу України під мантри про «невидиму руку вільного ринку», лібералізацію зовнішньої торгівлі, приватизацію і послаблення державного регулювання.

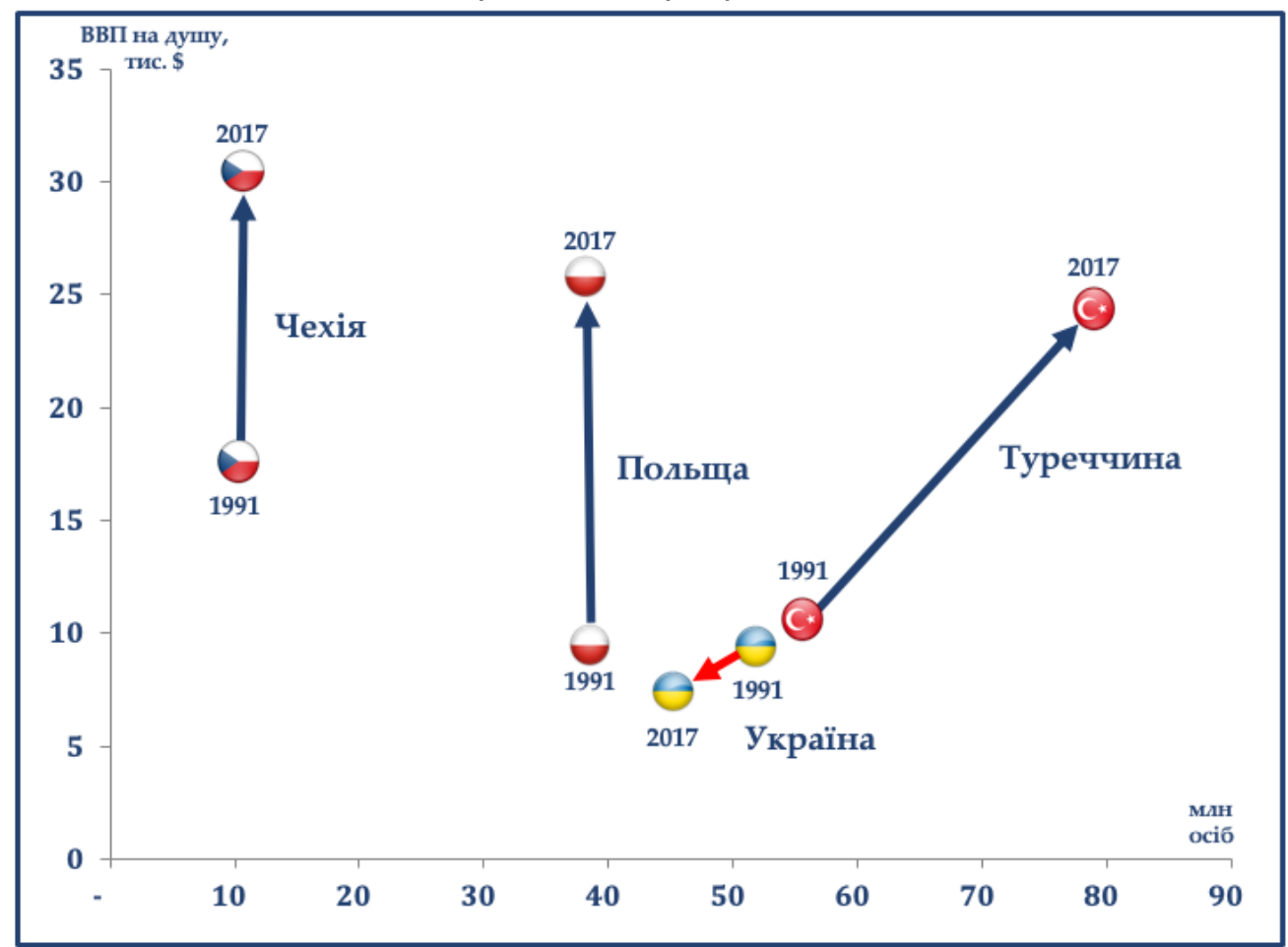

Рис. 2. Двовимірна соціально-економічна динаміка України та сусідніх країн

Джерело: [9; 15]

Ще більш красномовним $є$ порівняння соціально-економічного шляху, пройденого за цей час Україною та «Азійськими тиграми». Це був діаметрально протилежний шлях як в економічному, так і в де- 
мографічному вимірі. «Азійські тигри», відомі своїм «економічним дивом», суттєво підняли рівень добробуту громадян і збільшили чисельність населення. Україна ж втратила, грубо кажучи, чверть економіки та населення.

Я наголошував, що Україна поки не Європа економічно. А коли ж ми подолаємо 5-кратний економічний розрив з ЄС? Якщо радикально не міняти економічну політику, то ніколи. Адже економічні траєкторії України та ЄС не зближуються, а розходяться. Замість конвергенції доходів українців та громадян країн ЄС, очікуваної в контексті євроінтеграційних прагнень та кроків України, бачимо протилежний процес. Україна все більше віддаляється від ЄС за рівнем розвитку.

Парадоксально, що економічну дивергенцію траєкторій України і ЄС практично не обговорюють вголос ані всередині країни, ані, тим більше, на міжнародній арені. Після економічного обвалу 2014-2015 років, спричиненого російською військовою агресією, втратою виробничих потужностей і ринків, у 2016-2018 роках українська економіка показала середньорічний приріст близько 2,7\% [11]. Це, до речі, близько до темпу зростання економіки ЄС. Проте, оскільки база відрізняється в рази, при однакових темпах зростання наша економіка невідворотно відстає від європейської. Причому «швидкість» такого відставання в термінах «гроші/час» невпинно наростає. Треба зауважити також, що європейська економіка далеко не найбільш динамічна у світі. Прогноз зростання глобальної економіки - 3,5\% у 2019 році та $3,6 \%$ у 2020 році [16].

Щоб наздоганяти ЄС в досяжній перспективі нам треба розвиватись хоча б вдвічі швидшими темпами. Значить 7\% - мінімальна планка, «minimum minorum» річного зростання української економіки. Нижчі темпи не можуть вважатись успішними апріорі. Як би нас не переконували у зворотному МВФ, Світовий Банк чи будь-хто ще. Дуже важливо осмислити цей неочевидний і досить некомфортний факт. I належним чином інкорпорувати його при реалізації політики євроінтеграції.

Сьогодні в економічному вимірі замість євроінтеграції, якої щиро прагне українське суспільство і за яку українці віддавали життя під час Євромайдану, ми спостерігаємо процес «євроімітації». Це жодним чином не слід трактувати як заклик до зміни геополітичного вектору чи євроскептицизму. Навпаки, варто особливо підкреслити принципову важливість наповнення євроінтеграції реальним змістом корисним для українців: підвищення рівня реальних доходів людей та наближення стандартів життя до європейських.

Закордоном високо оцінюють прогрес українських реформ. Втім цікаво, як в контексті проваджуваних реформ світові експерти ба- 
чать економічні перспективи України. Деякі дослідницькі установи прогнозують економічну та демографічну динаміку різних країн не лише на 3-5 роки наперед, а навіть на 25 і більше років. В аналітичному підрозділі «The Economist» стверджують про перспективи України таке: «Ми прогнозуємо, що середньорічний приріст реального ВВП України на душу населення у 2018-2050 роках складе 2,1\%. Темпи зростання будуть стримуватись несприятливими демографічними тенденціями». При цьому в The Economist Intelligence Unit наголошують, що це, фактично ще й оптимістичний сценарій, який враховує проведення структурних реформ і зростання продуктивності: «Структурні реформи, якщо вони будуть впроваджені, прокладуть шлях до інституційних вдосконалень, що дозволить збільшити зростання за рахунок підвищення продуктивності. Однак, ми вважаємо, що уряд не буде здійснювати значні реформи, навіть у довгостроковій перспективі. ВВП України на душу населення в умовах паритету купівельної спроможності (ППС) залишиться лише часткою від середнього по ЄС» [17].

Такі темпи економічного зростання, які пророкує Україні The Economist Intelligence Unit на основі успішних на думку іноземних експертів реформ, призведуть до того, що Україна буде наздоганяти Туреччину зразку 2017 року 50 років, а Польщу зразку 2017 року взагалі наздожене не раніше 2080 року! Більш того, щоб досягнути рівня реального ВВП на душу населення, який Україна мала у 2013 році, нам знадобиться принаймні 10 років.

Уявіть який сигнал такі прогнози посилають міжнародним інвесторам! Чи спонукають вони вкладати в нашу країну? Усі держави в світі конкурують за інвестиції, адже вони створюють можливості, робочі місця, добробут, перспективу. Чи має Україна шанс вигравати у цій глобальній конкуренції, маючи прогноз довгострокових темпів зростання майже вдвічі нижчий, ніж демонструє світова економіка, і втричі нижчий, ніж темпи зростання економіки Китаю. Адже зазвичай інвестують в країни, економіки яких зростають швидше за конкурентів. Туди, де швидше підвищується добробут, а значить і купівельна спроможність громадян і ємність ринку.

Економічна політика, яку іноземні експерти і дипломати називають успішною, замість модернізації спричиняє стагнацію економіки. Нам розповідали, що за кредитами МВФ прийдуть приватні інвестиції, але цього не відбулось. Приплив прямих іноземних інвестицій в українську економіку протягом 2017-2018 років менше $\$ 2,5$ млрд на рік. Переважна частка з них, до речі, не вкладення у реальні виробництва, а конвертація боргів у капітал в фінансовому секторі.

Щоб наздогнати Польщу зразку 2018 року за рівнем інвестицій на душу населення нам необхідно залучити $\$ 200$ млрд. Якщо ми будемо рухатись нинішніми темпами, а Польща почекає нас на місці, 
ми ліквідуємо розрив за рівнем інвестицій через 80 років.

На відміну від західних дипломатів та неоліберальних експертів, українці це бачать, розуміють та відчувають. I саме тому мільйони наших співгромадян вимушено емігрують закордон у пошуках кращої долі. Причому, передусім, в ту ж саму Польщу. В результаті відтоку кадрів за кордон та перевищення смертності над народжуваністю формується довгостроковий негативний демографічний тренд. Особливо жахливо, що при такому розвитку подій населення України в 2050 році скоротиться до 37 мільйонів, а ще через 50 років до 28 мільйонів [18].

Це свідчить про те, що Україні потрібні не поверхневі фрагментарні неоліберальні реформи, а глибинна структурна трансформація економіки. Нинішні реформи дорівнюють консервації сировинної моделі економіки та продовженню стагнації. Лише цілеспрямована модернізація економіки, ставка на промисловий розвиток, розбудову сучасної інфраструктури та широке запровадження інновацій, а не сировинно-борговий дрейф чи паліативна фінансова допомога здатні вивести Україну з «глухого кута» на чільну економічну орбіту! Як колись проголосив генерал Де Голль у післявоєнній Франції: «Модернізація або смерть!». Ще раніше перший президент Туреччини Мустафа Кемаль Ататюрк говорив «Сплячі народи або зникають, або прокидаються рабами». I те й інше більш ніж актуально для України наших днів.

Висновки. Сьогодні Україна - глобальний ресурсний донор, що поставляє більш розвиненим країнам сировину, робочі руки і таланти та, як це не парадоксально, - кошти. Ціна помилкової державної політики за кілька десятирічь - втрата майже $30 \%$ економіки в реальному вимірі та майже 10 млн населення. Як наслідок - п'ятиразове економічне відставання від ЄС. Ми Європа географічно, цивілізаційно, але не за рівнем добробуту, якістю і тривалістю життя.

Разом з тим, перспективи України величезні, але постає необхідність вдало конвертувати їх у реальні можливості та добробут громадян; не змарнувати наявні ресурси і вийти на траєкторію сталого розвитку; не лишитись економічною і технологічною околицею $€_{\mathrm{B}-}$ ропи; створити умови для самореалізації українців на рідній землі, суттєво підняти рівень життя, зменшити соціальну нерівність та зберегти здорове навколишнє середовище?

Народ України заслуговує на краще життя i, безумовно, здатен змінити траєкторію і долю власної країни. Україна має все необхідне, щоб здійснити «фазовий перехід» від бідності й залежності до суспільного добробуту і суб'єктності на міжнародній арені, хоча на сьогодні перебуває на дуже низькій «економічній орбіті». Проте це абсолютно реально виправити. Це вже вдалося низці країн, де відбувалося так зване «економічне диво». 
Серія «Економічні науки»

Випуск 4(84) 2018 р.

Але якщо просто сидіти і чекати, цього ніколи не станеться. Марно сподіватися, що хтось ззовні - МВФ, ЄС чи хтось інший - зробить Україну успішною. Результат залежить від нас самих. І, насправді, потрібні не просто «реформи», а системна трансформація. Змінити економічну політику і економічну модель країни, концентруючи усі ресурси та зусилля в правильному напрямі. Як заповідав співзасновник Всесвітнього економічного форуму в Давосі, почесний член Римського клубу Б.Д. Гаврилишин у своїй доповіді для Римського клубу: «Нам доконечно треба збільшити темпи зростання ВВП до 8$10 \%$ щорічно, одночасно знижуючи інфляцію» [19, С. 245]. Відхід від неоліберальної парадигми в економічній політиці та перехід до цілеспрямованої індустріалізації дозволить досягнути цієї мети.

1. Данилишин Б. М. Економіка України: криза розвитку та перспективи модернізації : монографія. К. : Нічлава, 2010. 412 с. 2. Ещенко П. С. Украинская «великая депрессия» и как из нее выйти? К. : ВД «Дакор», 2017. 248 с. 3. Єщенко П. С. Економічне зростання без розвитку: причини і шляхи інноваційного перетворення економіки. Економіка України. 2013. № 10. С. 4-20. 4. Колінець Л. Б. Наслідки глобальних кризових явищ для економіки України. Науковий вісник Ужгородського національного університету. Міжнародні економічні відносини та світове господарство. 2018. Вип. 18(2). С. 54-57. 5. Квач Я. П. Про шляхи подолання кризи української економіки. Економіка: реалії часу. 2015. № 3. С. 6-11. 6. Голян В. А. Економічна криза в Україні: феномен "голландської хвороби" та рецидив "ресурсного прокляття". Економіка та держава. 2016. № 7. С. 4-15. 7. Гужва І. Ю. Актуалітети зовнішньоторговельної політики України : монографія. К. : Національна академія управління, 2017. 298 с. 8. Іванов Є. І. Обґрунтування державної політики диверсифікації зовнішньоторговельної сфери національної економіки. Вісник Одеського національного університету. Економіка. 2017. Вип. 11(64). C. 58-63. 9. GDP per capita, PPP (constant 2011 international \$). The World Bank data. URL: https://data.worldbank.org/indicator/NY.GDP.PCAP.PP.KD?view= chart. (Last accessed: 02.06.2019). 10. Quarterly National Accounts: GDP - income approach. OECS Statistics. URL: https://stats.oecd.org/Index.aspx?Queryld=77. (Last accessed: 02.06.2019). 11. Валовий внутрішній продукт за 2017 рік (CHP-2008'). Державна служба статистики України. URL: http://www.ukrstat.gov.ua/operativ/operativ2017/vvp/vvp_kv/vvp_kv_u/vvpf kv2017u.htm. (дата звернення: 02.06.2019). 12. GDP (constant 2010 US\$). The World Bank data. URL: https://data.worldbank.org/indicator/NY.GDP.MKTP.KD?view=chart. (Last accessed: 02.06.2019). 13. Medina L., Schneider F. Shadow Economies Around the World: What Did We Learn Over the Last 20 Years? IMF Working Paper. 2018. URL: https://www.imf.org/ /media/Files/Publications/WP/2018 /wp1817.ashx. (Last accessed: 02.06.2019). 14. ArcGIS Online. URL: https://www.arcgis.com. (Last accessed: 02.06.2019). 15. Population, total. The World Bank data. URL: https://data.worldbank.org/indicator/SP.POP.TOTL. (Last accessed: 02.06.2019). 16. World Economic Outlook Report. International 
Monetary Fund. URL: https://www.imf.org/en/publications/weo. (Last accessed: 02.06.2019). 17. Economy: Long-term outlook - Ukraine. The Economist Intelligence Unit.

URL: http://country.eiu.com/article.aspx?articleid=1057121489\&Country= Ukraine\&topic =Economy\&subtopic $=$ Long-term+outlook\&subsubtopic =Summary. (Last accessed: 02.06.2019). 18. World Population Prospects 2017. United Nations DESA. Population division. URL: https://population.un.org/wpp/ Graphs/Probabilistic/POP/TOT. (Last accessed: 02.06.2019). 19. Гаврилишин Б. Д. До ефективних суспільств: дороговкази в майбутнє: доп. Римському Клубові. / упоряд. В. Рубцов. Вид. 3-тє, допов. К. : Унів. видво ПУЛЬСАРИ, 2009. 248 с.

\section{REFERENCES:}

1. Danylyshyn B. M. Ekonomika Ukrainy: kryza rozvytku ta perspektyvy modernizatsii : monohrafiia. K. : Nichlava, 2010. 412 s. 2. Eshchenko P. S. Ukrainskaia «velikaia depressiia» i kak iz nee vyity? K. : VD «Dakor», 2017. 248 s. 3. Yeshchenko P. S. Ekonomichne zrostannia bez rozvytku: prychyny i shliakhy innova-tsiinoho peretvorennia ekonomiky. Ekonomika Ukrainy. 2013. № 10. S. 4-20. 4. Kolinets L. B. Naslidky hlobalnykh kryzovykh yavyshch dlia ekonomiky Ukrainy. Naukovyi visnyk Uzhhorodskoho natsionalnoho universytetu. Mizhnarodni ekonomichni vidnosyny ta svitove hospodarstvo. 2018. Vyp. 18(2). S. 54-57. 5. Kvach Ya. P. Pro shliakhy podolannia kryzy ukrainskoi ekonomiky. Ekonomika: realii chasu. 2015. № 3. S. 6-11. 6. Holian V. A. Ekonomichna kryza v Ukraini: fenomen "hollandskoi khvoroby" ta retsydyv "resursnoho prokliattia". Ekonomika ta derzhava. 2016. № 7. S. 4-15. 7. Huzhva I. Yu. Aktualitety zovnishnotorhovelnoi polityky Ukrainy : monohrafiia. K. : Natsionalna akademiia upravlinnia, 2017. 298 s. 8. Ivanov Ye. I. Obgruntuvannia derzhavnoi polityky dyversyfikatsii zovnishnotorhovelnoi sfery natsionalnoi ekonomiky. Visnyk Odeskoho natsionalnoho universytetu. Ekonomika. 2017. Vyp. 11(64). S. 58-63. 9. GDP per capita, PPP (constant 2011 international \$). The World Bank data. URL: https://data.worldbank.org/indicator/NY.GDP.PCAP.PP.KD?view= chart. (Last accessed: 02.06.2019). 10. Quarterly National Accounts: GDP - income approach. OECS Statistics. URL: https://stats.oecd.org/Index.aspx?Queryld=77. (Last accessed: 02.06.2019). 11. Valovyi vnutrishnii produkt za 2017 rik (SNP20081). Derzhavna sluzhba statystyky Ukrainy. URL: http://www.ukrstat.gov.ua/operativ/operativ2017/vvp/vvp_kv/vvp_kv_u/vvpf_ kv2017u.htm. (data zvernennia: 02.06.2019). 12. GDP (constant 2010 US\$). The World Bank data. URL: https://data.worldbank.org/indicator/NY.GDP.MKTP.KD?view=chart. (Last accessed: 02.06.2019). 13. Medina L., Schneider F. Shadow Economies Around the World: What Did We Learn Over the Last 20 Years? IMF Working Paper. 2018. URL: https://www.imf.org/ /media/Files/Publications/WP/2018 /wp1817.ashx. (Last accessed: 02.06.2019). 14. ArcGIS Online. URL: https://www.arcgis.com. (Last accessed: 02.06.2019). 15. Population, total. The World Bank data. URL: https://data.worldbank.org/indicator/SP.POP.TOTL. (Last accessed: 02.06.2019). 16. World Economic Outlook Report. International 
Серія «Економічні науки»

Випуск 4(84) 2018 р.

Monetary Fund. URL: https://www.imf.org/en/publications/weo. (Last accessed: 02.06.2019). 17. Economy: Long-term outlook - Ukraine. The Economist Intelligence Unit. URL: http://country.eiu.com/article.aspx?articleid $=1057121489 \&$ Country= Ukraine\&topic $=$ Economy\&subtopic $=$ Long-term+outlook\&subsubtopic =Summary. (Last accessed: 02.06.2019). 18. World Population Prospects 2017. United Nations DESA. Population division. URL: https://population.un.org/wpp/ Graphs/Probabilistic/POP/TOT. (Last accessed: 02.06.2019). 19. Havrylyshyn B. D. Do efektyvnykh suspilstv: dorohovkazy v maibutnie: dop. Rymskomu Klubovi. / uporiad. V. Rubtsov. Vyd. 3-tie, dopov. K. : Univ. vyd-vo PULSARY, 2009. $248 \mathrm{~s}$.

Рецензент: д.е.н., професор Савіна Н. Б. (НУВГП)

Halasiuk V. V., Candidate of Economics (Ph.D.), Chairman of the Committee on Industrial Policy and Enterprise of the Verkhovna Rada of Ukraine, President of the Ukrainian Association of the Roman Club

\section{TOPICAL PROBLEMS OF UKRAINE IN ACHIEVING A POSITIVE TRAJECTORY OF ECONOMIC GROWTH}

The article deals with issue of overcoming the chronic problems of the Ukrainian economy and ensuring its advanced development on the path of European integration. The purpose of the article is to determine key causes and consequences of Ukraine's ineffective model of development in the period of market transformations and to argue the necessity of radical revision of the fundamental principles and approaches to state economic policy implementation. The trends of economic decline in Ukraine during transition to a market economy are described. It is stressed that Ukrainian economy needs urgent professional diagnosis, reanimation and development, not imitation of reforms by means of non-interference policy that led to "free economic fall". The reason for discrepancy between official macroeconomic statistics and real standard of living in Ukraine during 1990-2017 is explained. A comparative analysis of the socio-economic dynamics of Ukraine and a number of other countries, which had roughly identical starting positions in the development of the national economy at the end of the twentieth century, is conducted. The author emphasizes that the current economic policy in Ukraine, which foreign experts and diplomats regard as successful, actually causes stagnation of the economy. The challenges of European integration for Ukraine in the context of ensuring economic convergence with the EU are identified. The necessity for a profound structural transformation of the domestic economy, as opposed to the superficial neoliberal 
reforms carried out in the time of independence, is proved. The author concludes that withdrawal from a neoliberal paradigm in economic policy and transition to a deliberate industrialization will allow to increase the Ukraine's GDP growth rate to 8-10 per cent annually and to catch up with developed countries.

Keywords: gross domestic product, commodity-debt drift, economic decline, structural transformation, European integration, economic development, economic policy.

Галасюк В. В., к.э.н., Председатель Комитета Верховной Рады Украины по вопросам промышленной политики и предпринимательства, Президент Украинской ассоциации Римского Клуба

\section{АКТУАЛЬНЫЕ ПРОБЛЕМЫ ВЫХОДА УКРАИНЫ НА ПОЗИТИВНУЮ ТРАЕКТОРИЮ ЭКОНОМИЧЕСКОГО РОСТА}

В статье затронута проблема преодоления хронических проблем украинской экономики и обеспечения ее опережающего развития на пути европейской интеграции. Охарактеризованы тенденции экономического упадка в Украине во времена перехода к рыночной экономике. Проведен сравнительный анализ социальноэкономической динамики Украины и ряда других стран имели примерно одинаковые с ним стартовые позиции развития национального хозяйства в конце $\mathrm{XX}$ в. Определены вызовы европейской интеграции для Украины в контексте обеспечения экономической конвергенции с ЕС. Обоснована необходимость глубокой структурной трансформации отечественной экономики в противовес поверхностным неолиберальным реформам, проведенных за время независимости.

Ключевые слова: валовой внутренний продукт, сырьевыми долговой дрейф, экономический упадок, структурная трансформация, евроинтеграция, экономическая политика, экономическое развитие. 